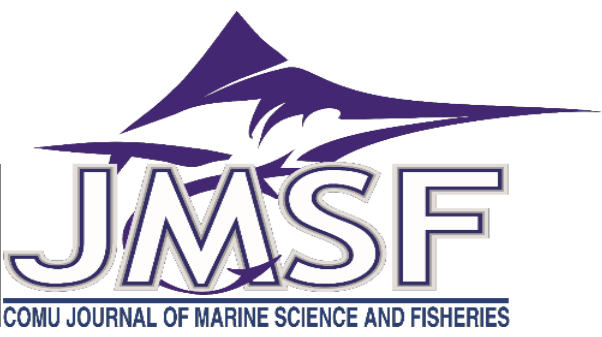

RESEARCH ARTICLE

\title{
Evaluation of Fish Micronucleus Results in Turkish Ecogenotoxicological Studies
}

\author{
Gülşen Göney ${ }^{1 *}$, Cengiz Gazeloğlu ${ }^{2}$ \\ ${ }^{1}$ Süleyman Demirel University, Faculty of Pharmacy, Department of Toxicology, 32260, Çünür, Isparta, Turkey \\ ${ }^{2}$ Süleyman Demirel University, Faculty of Arts and Sciences, Department of Statistics, 32260, Çünür, Isparta, Turkey \\ Correspondent: gulsengoney@sdu.edu.tr \\ Received: 06.12.2019 Accepted: 05.03.2020 \\ Gülşen Göney: Orcid 0000-0002-5236-1241, Cengiz Gazeloğlu: Orcid 0000-0002-8222-3384
}

How to cite this article: Göney, G., \& Gazeloğlu, C., (2020). Evaluation of fish micronucleus results in Turkish ecogenotoxicological studies. COMU J. Mar. Sci. Fish, 3(1): 1-10. DOI: 10.46384/jmsf.654156

\begin{abstract}
In recent years, ecotoxicological studies have been conducted around the world, especially in aquatic ecosystems. It is noteworthy that genotoxicity tests have been frequently used in the biomonitoring of pollution. The present study evaluates genotoxicity tests including comet assays, micronucleus assays, fluorescent in-situ hybridization assays, chromosomal aberration assays, and sister chromatid exchange assays used in fish species for biomonitoring of environmental pollution in Turkey. Thirty-six ecotoxicological studies, which aimed to investigate possible genotoxic damage in fish species between the years 1970 and 2016, were analyzed. As a result of the literature review, it was concluded that the largest number of studies were done in 2011 . There were micronucleus assays in $83.33 \%$, comet assays in $30.55 \%$, chromosomal aberration assays in $5.55 \%$, and sister chromatid exchange experiments in $2.77 \%$ of the studies. Most of the micronucleus experiments were performed in eco-genotoxicological studies. Our results show that there were no statistically significant differences $(p>0.05)$ between the erythrocyte and gill samples in the micronucleus results from the studies. This study is the first assessment of the use of genotoxicity tests in ecotoxicological studies in Turkey. Considering the principle of refinement in $4 \mathrm{R}$ theory our results show that the use of gill cells instead of peripheral erythrocytes would be more appropriate in micronucleus assays.
\end{abstract}

Keywords: Genotoxicity, Micronucleus, Environmental Pollution, Aquatic Toxicity, Ecotoxicology

\section{Türkiye'deki Ekogenotoksikolojik Çalışmalarda Balık Mikroçekirdek Sonuçlarının Değerlendirilmesi}

Özet: Son yıllarda, dünya genelinde ekogenotoksikolojik çalışmalar özellikle sucul ekosistemlerde yürütülmektedir. Kirliliğin biyoizlenmesine yönelik olarak genotoksisite testlerinin sıklıkla kullanımı da dikkat çekmektedir. Sunulan çalışmada, Türkiye'de çevresel kirliliğin biyoizlenmesinde Comet, Mikroçekirdek, Floresan in Situ Hibridizasyon, Kromozomal aberasyon ve Kardeş kromatid değişimi genotoksisite testlerinin kullanımı değerlendirilmiştir. Bu amaçla 1970-2016 tarihleri arasında yapılmış olan balık türlerinde olası genotoksik hasarın araştırıldığı çalışmalar analiz edilmiştir. Literatür araştırması sonucunda en fazla çalışmanın 2011 yılında yapıldığı ortaya çıkartılmıştır. Çalışmaların \%83.33'ünde mikroçekirdek, \%30.55'inde comet, \%5.55'inde kromozomal aberasyon deneyi ve \%2.77'sinde kardeş kromatid değişimi deneyi kullanılmıştır. Ekogenotoksikolojik çalışmalarda en fazla kullanılan deney Mikroçekirdek deneyidir. Mikroçekirdek deney sonuçlarına yönelik yapılmış olan istatistiksel analiz sonucunda eritrosit ve solungaç hücreleri arasında mikroçekirdek sonuçları bakımından istatistiksel olarak anlamlı bir farklılılık bulunmadığı $(p>0.05)$ ortaya çıkartılmıştır. Sunulan çalışma Türkiye'de yapılmış olan ekotoksikolojik çalışmalarda genotoksisite testlerinin değerlendirildiği ilk çalışmadır. 4 R kuramında "iyileştirme" ilkesi dikkate alındığında, çalışma sonuçlarımız mikroçekirdek deneyinde periferal eritrositler yerine solungaç hücrelerinin kullanımının daha uygun olabileceğini göstermektedir.

Anahtar Kelimeler: Genotoksisite, Mikroçekirdek, Çevresel Kirlilik, Sucul Toksisite, Ekotoksikoloji 


\section{Introduction}

Developments in some industries have included excessive production and use of chemicals. The bioaccumulation of toxic compounds is observed, as some chemicals remain a long time in water, leading to increased environmental pollution. Increases in human population and development of the industry are reasons for industrial pollution. This pollution is caused by the accumulation of genotoxic and carcinogenic compounds in the oceans and lakes (Gobas, 2018). Biomonitoring plays a crucial role in governmental and industrial strategies to identify, assess, control, and decrease these problems. Sensitive and practical techniques in biomonitoring are needed for all approaches to these problems. Strategies include rating and classification of toxic chemicals, control of pollution sources, monitoring the status of pollution and trends in the changes in pollution, and assessments of "aquatic ecosystem health" (Wells, 1999). Fish species have attracted much attention in the biomonitoring of water pollution due to their special biological characteristics, including relatively big body size, long life cycle, ease of raising, and similar characteristics. More importantly, fish species are at the top position in the aquatic food chain and may directly affect the health of humans. This fact increases the significance of biomonitoring using fish (Al Sabti \& Metcalfe, 1995; Schweitzer \& Noblet, 2018). In the early 1990s, genotoxicity tests of fish species were also suggested to examine the toxicity of pollutants. These tests include comet assays, micronucleus assays, and chromosomal aberration tests of fish species (Al Sabti \& Metcalfe 1995). These were proposed to evaluate water pollution and were widely used as the main biomonitoring methods (Žegura \& Filipič, 2019; Anbumani \& Mohankumar, 2019). Also, positive correlations between comet assay results and micronucleus formation (i.e., biomarkers of 'exposure' and 'effects', respectively) have in general been found in fish cells under in vitro and in vivo conditions, respectively (Raisuddin \& Jha, 2004; Klobucar et al., 2006). These fish genotoxicity tests are excellent biomarkers for measuring pollution levels and the genotoxicity of water habitats. Biomarkers are measurements that more or less specifically quantitate exposure and early stage biological effects (Hussain et al., 2018). Biomarkers of early biological effects, e.g., chromosome aberrations and micronucleus frequency, detect a) early warnings of environmental damage; b) the integrated effect of a variety of environmental stresses on the health of an organism and the population, community, and ecosystem; c) relationships between the individual responses of exposed organisms to pollution and the effects of this exposure at the population level; d) early warnings of potential harm to human health based on the responses of wildlife to pollution; and f) the efficacy of treatment efforts in decontaminating waterways (Villela et al. 2006; Obiakor et al. 2012). The comet assay, micronucleus assay, and chromosomal aberration tests all play important roles in genetic ecotoxicology to determine induced genetic damage (Table 1), which has significant consequences for short- and long-term survival of the natural or wild species (Jha, 2008)

In the present study, we evaluated the comet assay, the micronucleus (MN) assay, the fluorescent in situ hybridization micronucleus (FISH-MN) assay, the chromosomal aberration (CA) assay, and the sister chromatid exchange (SCE) genotoxicity tests used in ecotoxicological studies from fish species in Turkey. The study aimed to a) identify the research studies that have focused on biomonitoring of environmental pollution in fish species, b) identify genotoxicity tests used in those studies, and c) provide a quantitative summary about the number of species, the number of genotoxicity tests, and the number of samples. These data are critical for a comprehensive evaluation of how genotoxicity tests impact the biomonitoring of environmental pollution in Turkey.

\section{Material and Methods}

The purpose of this research was to analyze articles in journals from 1970 through 2016 on the subject of eco-genotoxicology. Specifically, we analyzed the quality and quantity of articles from Turkey. The research studies were selected according to certain criteria. The criteria included the following: being conducted in Turkey, being focused on ecotoxicological studies, doing genotoxicity experiments in fish species, using the types of biomarkers under consideration in this study, and being published in peer-reviewed national or international journals. This is a descriptive study. The reason for taking 1970 as a starting date is that only after this date did genotoxicity experiments start to appear in scientific studies. For each study, the genotoxicity experiments, the examined species, and the type of the tissue samples studied (e.g., blood, intestines, stomach, kidney, gill tissues, or other tissues) were investigated. In addition, the bioindicators (biomonitoring of exposure, biomonitoring of effects, or biomonitoring of sensitivity) used in these studies were also recorded. To assess the quantitative relationship between shortterm genotoxicity and long-term carcinogenicity, a literature search was performed for the following short-term genotoxicity assays: the comet assay, the MN assay, and the CA assay. For each study, the relation between the pollutant and the genotoxicity test results were examined. When it was concluded that the pollutant caused the genotoxic damage, the result of the examination was assigned as positive. If otherwise, the result was considered negative. In this 
way, all publications were investigated. Statistical investigation of any difference between mean $\mathrm{MN}$ values of erythrocyte and gill samples in scientific publications was also in the scope of this study. For this analysis, the following hypotheses were constructed.

$\mathrm{H}_{0}$ : There is no statistically significant difference in the mean MN values of erythrocyte and gill samples.

$\mathrm{H}_{1}$ : There is a statistically significant difference in the mean MN values of erythrocyte and gill samples.

The statistical analyses of this study were conducted using SPSS software. As there are two independent groups in the samples, t-tests were also conducted to determine the differences in the mean values of the corresponding groups.

\section{Results and Discussion}

The search yielded 8740 studies. After detailed examinations, 36 studies were included in the descriptive study. As a result of the literature review, the highest number of studies related to the use of genotoxicity tests in environmental pollution biomonitoring was published in 2011. The most used experimental method was the MN assay (Table 1).

Table 1: Ecotoxicological studies according to years and experiments in studies (Comet, MN, Aberration, SCE numbers)

\begin{tabular}{|l|c|r|r|r|r|}
\hline $\begin{array}{l}\text { Study } \\
\text { years }\end{array}$ & $\begin{array}{l}\text { Number of } \\
\text { studies }\end{array}$ & Comet & MN & Aberration & SCE \\
\hline 2001 & 1 & - & 1 & 1 & 1 \\
\hline 2002 & - & - & - & - & - \\
\hline 2003 & 2 & & 2 & - & - \\
\hline 2004 & - & - & - & - & - \\
\hline 2005 & 5 & - & 5 & - & - \\
\hline 2006 & - & - & - & - & - \\
\hline 2007 & 3 & 1 & 3 & - & - \\
\hline 2008 & 5 & 1 & 5 & - & - \\
\hline 2009 & 1 & - & 1 & 1 & - \\
\hline 2010 & 4 & - & 4 & - & - \\
\hline 2011 & 6 & 5 & 3 & - & - \\
\hline 2012 & 3 & 1 & 2 & - & - \\
\hline 2013 & - & - & - & - & - \\
\hline 2014 & 1 & 1 & 1 & - & - \\
\hline 2015 & 3 & 1 & 2 & - & - \\
\hline 2016 & 2 & 1 & 1 & - & - \\
\hline
\end{tabular}

More precisely, $83.33 \%$ of the studies contained $\mathrm{MN}$ tests, $30.55 \%$ contained a comet analysis, $5.55 \%$ studied chromosomal aberration, and $2.77 \%$ had sister chromatid exchange assays. The results of the analyses are shown in Figure 1. This figure shows the detected mean $\mathrm{MN}$ values and their standard deviations in erythrocyte samples from the Solea solea, Boops boops, Gobius niger, Serranus cabrilla, Carassius auratus, Pagellus erythrinus, Oreochromis niloticus, Diplodus vulgaris, Capoeta capoeta, Garra rufa, Mugil cephalus, Leuciscus cephalus, Clarias gariepinu, Alburnus oronti, Danio rerio, Orthrias angorae, and Cyprinus carpio species. The highest MN value was detected as 31.0 from Solea solea, with a standard deviation of 8.0. The second-highest MN value was 27.2 from Boops boops, with 5.4 as standard deviation. The lowest detected $\mathrm{MN}$ value from erythrocyte samples was 1.2 (standard deviation 0.3 ) from Cyrinus carpio, and the second-lowest was 2.2 (standard deviation 1.1), from Orthrias angorae. These and other species' erythrocyte samples' mean $\mathrm{MN}$ values are illustrated in Figure 1.

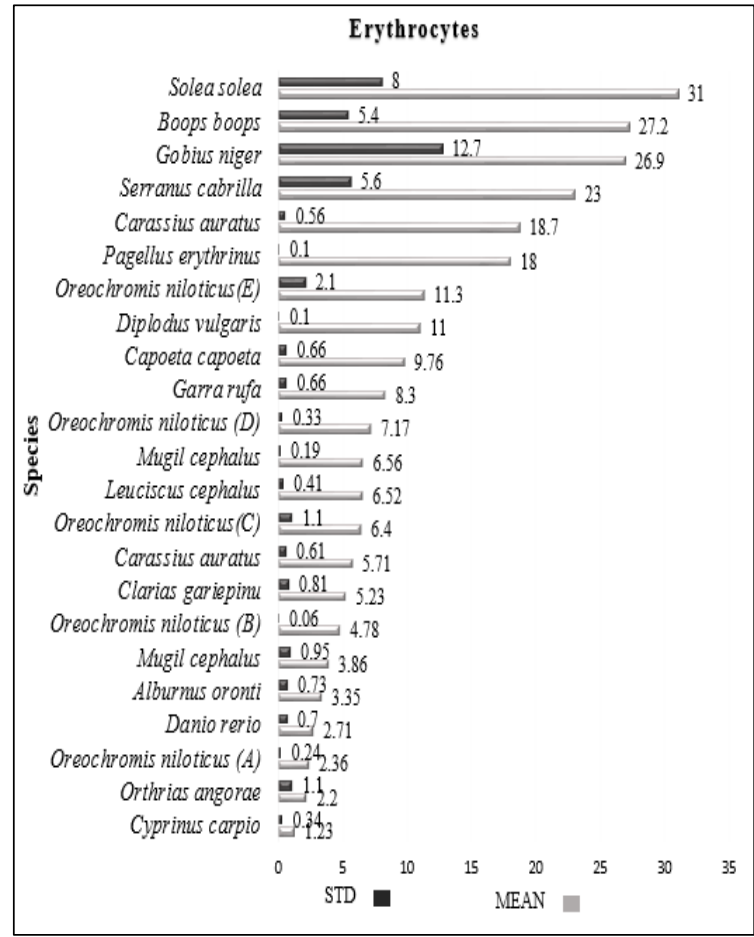

* In the figure, when there was more than one publication describing the same species, the studies are listed as A, B, C, D, E.

Figure 1: Mean values and standard deviations of erythrocyte MN values*

Figure 2 presents the mean $\mathrm{MN}$ values and standard deviations detected from the gill cell samples from Solea solea, Serranus cabrilla, Gobius niger, Boops boops, Oreochromis niloticus, Pagellus erythrinus, Diplodus vulgaris, Mugil cephalus, and Carassius auratus species. Here again, the highest value was from Solea solea (Figure 2) with a standard deviation of 1.24. The lowest detected mean $\mathrm{MN}$ value from the microscopic readings of gill cell samples was 3.83 from Orechromis niloticus, followed by 9.26 from Carassius auratus, with standard deviations of 0.5 and 1.3 , respectively. The most striking result, as shown in Figure 2, was from Gobius niger, with a standard deviation of 36.4 , the highest standard deviation value of the sample set. 


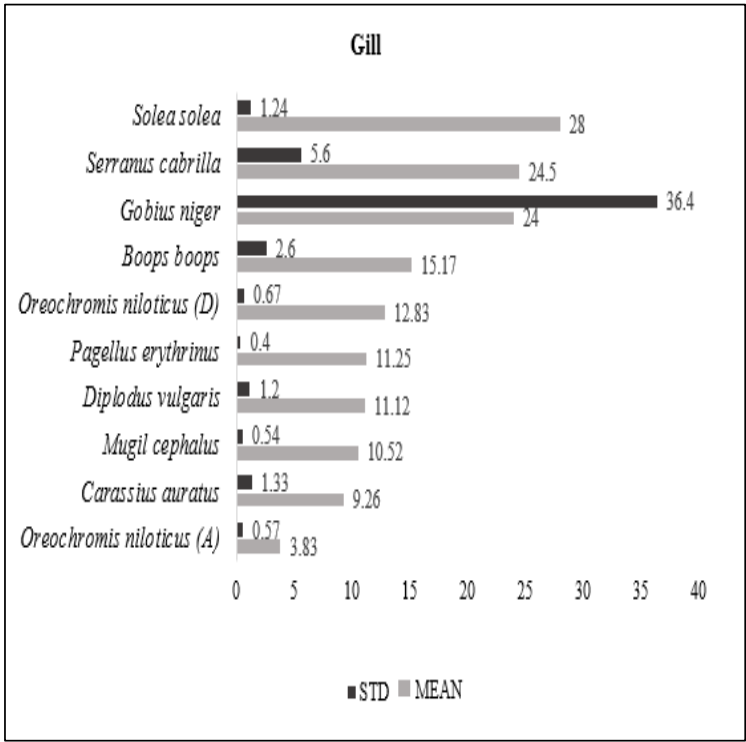

Figure 2: Mean MN values and standard deviations of gill samples

As shown in Table 2, the mean of the means of all 23 different studies which examined erythrocyte $\mathrm{MN}$ values was 10.5757 . From the 10 studies reporting gill cell sample mean $\mathrm{MN}$ values from 9 different species, the mean of all the studies was 15.0480.

Table 2. Mean MN values and sample numbers of erythrocyte and gill samples

\begin{tabular}{|l|c|c|c|}
\hline Sample & n & Mean & Sig. (p) \\
\hline Erythrocyte & 23 & 10.5757 & \multirow{2}{*}{$0.183^{*}$} \\
\cline { 1 - 3 } Gill & 10 & 15.0480 & \\
\hline${ }^{*} p>0.05$ & &
\end{tabular}

We investigated whether there is any statistically significant difference between erythrocyte and gill cell sample mean $\mathrm{MN}$ values. With a $95 \%$ confidence interval, no statistically significant difference was found. Hence the null hypothesis $\mathrm{H}_{0}$ was accepted ( $\mathrm{p}$ $=0.183>0.05$ ). The most valuable result of this study is that there were no differences found among the micronucleus results from samples taken from different tissues (erythrocyte and gill). Among the studies examined in this study, only four included comet assay test applications or tail moment values. These measurements were from two different species, Cyprinus carpio L. and Oncorhynchus mykiss. The values were $1.50 \pm 1.4 \mu \mathrm{m}$ (Çok et al., 2011), $16.5 \pm$ $2.22 \mu \mathrm{m}$ (Doğan et al., 2011), $28.4 \pm 24.3 \mu \mathrm{m}$ (Altınok et al., 2012), and $1.99 \pm 0.54 \mu \mathrm{m}$ (Demir et al., 2015). As the number of studies was low, no statistical evaluation was possible. Some possible reasons for studies' overall lower preference for comet assays are that it is a time-consuming assay, it is expensive, and it requires special laboratory conditions.

Table 3 shows a variety of results reached through this study. We observed that $77.77 \%$ of the studies evaluated only the impact of bioindicators, while the remaining $22.22 \%$ evaluated both exposure and impact. We found that $83.33 \%$ used only one species, whereas the remaining $16.66 \%$ studied more than one species. The evaluation of the results of all 36 studies showed that there was a positive significant correlation between contaminant factors and genotoxicity test results in $86.11 \%$ of the studies. In the remaining $13.88 \%$, no statistically significant correlation was found (Table 3).

\section{Conclusion}

Biomonitoring plays a vital role in governmental and industrial strategies to identify, assess, control, and reduce environmental pollution. At the cellular level, the MN assay, FISH-MN assay, comet assay, chromosomal aberration assay, and the sister chromatid exchange test are among the most widespread assessments used in various fish tissues to evaluate genotoxicity in water. The application of fish micronucleus tests in pollution monitoring, particularly in water, has been described as a sensitive biodetector of genotoxins (Klobučar et al., 2006, Kumar et al., 2017; Kaur et al., 2018; Žegura \& Filipič, 2019; Anbumani \& Mohankumar, 2019). The pervasiveness of these techniques is due to the variety of sensitivities available. These techniques are adequate as forms of early warning of ecological damage, toxicity, and stresses to the health of organisms and ecosystems.

Aquatic environmental pollution is a serious and growing problem. Humans are exposed throughout their lifetime to several xenobiotics present in both water and aquatic food. Importantly, fish species are at the top position in the aquatic food chain and may directly affect the health of humans. This fact gives biomonitoring using fish much significance. The present study evaluated the micronucleus tests used as biological indicators of chemical contamination in fish species. We recommend the use of the genotoxicity tests in fish as sensitive monitors for aquatic pollution. It is important that ethics of involving animals in research. The $4 \mathrm{R}$ 's refer to replacement, reduction, refinement and rehabilitation. Refinement it means minimize pain, suffering and distress and allow general improvement of animal welfare. When refinement is taken into consideration, our study results recommend it is more appropriate to carry out micronucleus test with gill samples instead of peripheral blood erythrocyte samples. In the future, further researches are needed which compared genotoxicity test results from different tissues in fish species. 
Table 3. Eco-genotoxicological studies in fish species

\begin{tabular}{|c|c|c|c|c|c|}
\hline $\begin{array}{l}\text { Genotoxicity } \\
\text { test type }\end{array}$ & Sample & Biomonitoring & Species & Result of study & References \\
\hline $\begin{array}{l}\text { SCE, AA, } \\
\text { MN }\end{array}$ & $\begin{array}{l}\text { Intestines, } \\
\text { stomach, } \\
\text { kidney, and } \\
\text { gill tissues }\end{array}$ & Biological Effect & Umbra limi & Positive & Ulupınar and Okumuş, 2001 \\
\hline MN & Blood smears & Biological Effect & Garra rufa & Positive & Çavaş and Gözükara, 2003 \\
\hline \multirow[b]{3}{*}{ MN } & \multirow{3}{*}{$\begin{array}{l}\text { Gill epithelial } \\
\text { cells and } \\
\text { peripheral } \\
\text { blood } \\
\text { erythrocytes }\end{array}$} & \multirow[b]{3}{*}{ Biological Effect } & \multirow{3}{*}{$\begin{array}{l}\text { Oreochromis } \\
\text { niloticus }\end{array}$} & \multirow[b]{3}{*}{ Positive } & Çavaş andGözükara, 2003b \\
\hline & & & & & Çavaş and Gözükara, 2005 \\
\hline & & & & & Çavaş and Gözükara, 2005b \\
\hline MN & $\begin{array}{l}\text { Peripheral } \\
\text { blood } \\
\text { erythrocytes, } \\
\text { gill epithelial } \\
\text { cells, and } \\
\text { liver cells }\end{array}$ & Biological Effect & $\begin{array}{l}\text { Cyprinus } \\
\text { carpio, } \\
\text { Carassius } \\
\text { gibelio } \\
\text { Corydoras } \\
\text { paleatus }\end{array}$ & Positive & Çavaş et al., 2005 \\
\hline MN & $\begin{array}{l}\text { Peripheral } \\
\text { blood } \\
\text { erythrocytes } \\
\text { and gill cells }\end{array}$ & Biological Effect & Mugil cephalus & Positive & Çavaş and Gözükara 2005 \\
\hline MN & Erythrocytes & Biological Effect & $\begin{array}{l}\text { Lepomis } \\
\text { gibbosus }\end{array}$ & Positive & Koca et al., 2005 \\
\hline MN & $\begin{array}{l}\text { Peripheral } \\
\text { blood }\end{array}$ & Biological Effect & $\begin{array}{l}\text { Clarias } \\
\text { gariepinu, } \\
\text { Alburnus } \\
\text { oronti, } \\
\text { Mugil } \\
\text { cephalus, }\end{array}$ & Positive & Ergene et al., 2007 \\
\hline $\mathrm{MN}$ & $\begin{array}{l}\text { Peripheral } \\
\text { blood } \\
\text { erythrocytes, } \\
\text { gill cells, and } \\
\text { caudal fin } \\
\text { epithelial cells }\end{array}$ & Biological Effect & $\begin{array}{l}\text { Oreochromis } \\
\text { niloticus }\end{array}$ & Positive & Ergene et al., 2007b \\
\hline $\begin{array}{l}\text { MN and } \\
\text { Comet Assay }\end{array}$ & $\begin{array}{l}\text { Peripheral } \\
\text { erythrocytes }\end{array}$ & Biological Effect & $\begin{array}{l}\text { Carassius } \\
\text { auratus }\end{array}$ & Positive & Çavaş and Könen, 2007 \\
\hline $\begin{array}{l}\text { MN and } \\
\text { Comet Assay }\end{array}$ & $\begin{array}{l}\text { Peripheral } \\
\text { erythrocytes }\end{array}$ & Biological Effect & $\begin{array}{l}\text { Oreochromis } \\
\text { niloticus }\end{array}$ & Positive & Çavaş and Könen, 2008 \\
\hline $\mathrm{MN}$ & $\begin{array}{l}\text { Peripheral } \\
\text { erythrocytes }\end{array}$ & Biological Effect & $\begin{array}{l}\text { Oreochromis } \\
\text { niloticus }\end{array}$ & Positive & Könen and Çavaş, 2008 \\
\hline
\end{tabular}




\begin{tabular}{|c|c|c|c|c|c|}
\hline MN & $\begin{array}{l}\text { Peripheral } \\
\text { blood } \\
\text { erythrocytes, } \\
\text { gill, and fin } \\
\text { epithelial cells }\end{array}$ & Biological Effect & $\begin{array}{l}\text { Carassius } \\
\text { auratus } \\
\text { auratus }\end{array}$ & Positive & Çavaş, 2008 \\
\hline $\mathrm{MN}$ & $\begin{array}{l}\text { Peripheral } \\
\text { blood } \\
\text { erythrocytes }\end{array}$ & Biological Effect & $\begin{array}{l}\text { Orthrias } \\
\text { angorae }\end{array}$ & Positive & Gül et al., 2008 \\
\hline $\mathrm{MN}$ & $\begin{array}{l}\text { Gills, liver, } \\
\text { and muscle } \\
\text { tissue }\end{array}$ & $\begin{array}{l}\text { Exposure and } \\
\text { Biological Effect }\end{array}$ & $\begin{array}{l}\text { Chondrostoma } \\
\text { nasus and Bar } \\
\text { bus capito } \\
\text { pectoralis }\end{array}$ & Negative & Koca et al., 2008 \\
\hline $\begin{array}{l}\text { MN and } \\
\text { Chromosomal } \\
\text { Aberration }\end{array}$ & $\begin{array}{l}\text { Peripheral } \\
\text { erythrocytes }\end{array}$ & Biological Effect & Danio rerio & Positive & Şişman et al., 2009 \\
\hline $\mathrm{MN}$ & $\begin{array}{l}\text { Erythrocytes } \\
\text { and gills }\end{array}$ & Biological Effect & $\begin{array}{l}\text { Mytilus } \\
\text { Galloprovincia } \\
\text { lis, } \\
\text { Gobius niger }\end{array}$ & Positive & Arslan et al., 2010 \\
\hline $\mathrm{MN}$ & $\begin{array}{l}\text { Peripheral } \\
\text { blood } \\
\text { erythrocytes }\end{array}$ & Biological Effect & $\begin{array}{l}\text { Oreochromis } \\
\text { niloticus }\end{array}$ & Positive & Summak et al., 2010 \\
\hline $\mathrm{MN}$ & $\begin{array}{l}\text { Gills, liver, } \\
\text { and muscle }\end{array}$ & $\begin{array}{l}\text { Exposure and } \\
\text { Biological Effect }\end{array}$ & $\begin{array}{l}\text { Cyprinus } \\
\text { carpio }\end{array}$ & Negative & Gürcü et al., 2010 \\
\hline $\mathrm{MN}$ & $\begin{array}{l}\text { Blood from } \\
\text { gills }\end{array}$ & $\begin{array}{l}\text { Exposure and } \\
\text { Biological Effect }\end{array}$ & $\begin{array}{l}\text { Anguilla } \\
\text { anguilla }\end{array}$ & Negative & Yildiz et al., 2010 \\
\hline Comet Assay & $\begin{array}{l}\text { Peripheral } \\
\text { blood } \\
\text { erythrocytes }\end{array}$ & Biological Effect & $\begin{array}{l}\text { Cyprinus } \\
\text { carpio } \mathrm{L} .\end{array}$ & Positive & Çok et al., 2011 \\
\hline $\mathrm{MN}$ & $\begin{array}{l}\text { Peripheral } \\
\text { erythrocytes }\end{array}$ & Biological Effect & $\begin{array}{l}\text { Oreochromis } \\
\text { niloticus }\end{array}$ & Positive & Özkan et al., 2011 \\
\hline Comet Assay & $\begin{array}{l}\text { Peripheral } \\
\text { blood } \\
\text { erythrocytes }\end{array}$ & Biological Effect & $\begin{array}{l}\text { Oncorhynchus } \\
\text { mykiss }\end{array}$ & Positive & Doğan et al., 2011 \\
\hline $\begin{array}{l}\text { Comet Assay } \\
\text { (Modify } \\
\text { Comet) }\end{array}$ & $\begin{array}{l}\text { Peripheral } \\
\text { blood } \\
\text { erythrocytes }\end{array}$ & $\begin{array}{l}\text { Exposure and } \\
\text { Biological Effect }\end{array}$ & $\begin{array}{l}\text { Cyprinus } \\
\text { carpio L. }\end{array}$ & Positive & Mustafa et al., 2011 \\
\hline $\begin{array}{l}\text { MN and } \\
\text { Comet Assay }\end{array}$ & $\begin{array}{l}\text { Peripheral } \\
\text { blood } \\
\text { erythrocytes }\end{array}$ & $\begin{array}{l}\text { Exposure and } \\
\text { Biological Effect }\end{array}$ & $\begin{array}{l}\text { Cyprinus } \\
\text { carpio L. }\end{array}$ & Positive & Selvi et al., 2011 \\
\hline $\begin{array}{l}\text { MN and } \\
\text { Comet Assay }\end{array}$ & $\begin{array}{l}\text { Peripheral } \\
\text { blood } \\
\text { erythrocytes }\end{array}$ & Biological Effect & $\begin{array}{l}\text { Carassius } \\
\text { auratus }\end{array}$ & Positive & Çavaş, 2011 \\
\hline
\end{tabular}




\begin{tabular}{|c|c|c|c|c|c|}
\hline Comet Assay & $\begin{array}{l}\text { Blood } \\
\text { collection } \\
\text { from caudal } \\
\text { vein }\end{array}$ & $\begin{array}{l}\text { Exposure and } \\
\text { Biological Effect }\end{array}$ & $\begin{array}{l}\text { Oncorhynchus } \\
\text { mykiss }\end{array}$ & Positive & Altınok et al., 2012 \\
\hline $\mathrm{MN}$ & $\begin{array}{l}\text { Peripheral } \\
\text { blood samples } \\
\text { from the } \\
\text { caudal vein }\end{array}$ & Biological Effect & $\begin{array}{l}\text { Oreochromis } \\
\text { niloticus }\end{array}$ & Positive & Kan et al., 2012 \\
\hline $\mathrm{MN}$ & $\begin{array}{l}\text { Peripheral } \\
\text { blood }\end{array}$ & $\begin{array}{l}\text { Exposure and } \\
\text { Biological Effect }\end{array}$ & $\begin{array}{l}\text { Cyprinus } \\
\text { carpio }\end{array}$ & Negative & Gül et al., 2012 \\
\hline $\mathrm{MN}$ & $\begin{array}{l}\text { Peripheral } \\
\text { blood } \\
\text { erythrocytes, } \\
\text { gill epithelial } \\
\text { cells, and } \\
\text { liver cells }\end{array}$ & Biological Effect & $\begin{array}{l}\text { Leuciscus } \\
\text { cephalus, } \\
\text { Capoeta } \\
\text { capoeta, }\end{array}$ & Positive & Yazıcı and Şişman, 2014 \\
\hline $\mathrm{MN}$ & $\begin{array}{l}\text { Peripheral } \\
\text { blood and gill } \\
\text { cells }\end{array}$ & Biological Effect & $\begin{array}{l}\text { Solea solea } \\
\text { Pagellus } \\
\text { erythrinus } \\
\text { Diplodus } \\
\text { vulgaris } \\
\text { Serranus } \\
\text { cabrilla } \\
\text { Boops boops }\end{array}$ & Positive & Arslan et al., 2015 \\
\hline Comet assay & $\begin{array}{l}\text { Peripheral } \\
\text { blood }\end{array}$ & $\begin{array}{l}\text { Exposure and } \\
\text { Biological Effect }\end{array}$ & $\begin{array}{l}\text { Oncorhynchus } \\
\text { mykiss }\end{array}$ & Positive & Demir et al., 2015 \\
\hline $\mathrm{MN}$ & Erythrocytes & Biological Effect & $\begin{array}{l}\text { Oreochromis } \\
\text { niloticus }\end{array}$ & Positive & Mert et al., 2015 \\
\hline $\mathrm{MN}$ & $\begin{array}{l}\text { Peripheral } \\
\text { blood }\end{array}$ & Biological Effect & $\begin{array}{l}\text { Oreochromis } \\
\text { niloticus }\end{array}$ & Positive & Benli et al., 2016 \\
\hline Comet assay & $\begin{array}{l}\text { Semen } \\
\text { samples }\end{array}$ & Biological Effect & $\begin{array}{l}\text { Carassius } \\
\text { auratus }\end{array}$ & Negative & Kutluyer et al., 2016 \\
\hline
\end{tabular}

\section{Acknowledgements}

The author declared that this study has received no financial support

\section{References}

Al-Sabti, K., \& Metcalfe, C. D. (1995). Fish micronuclei for assessing genotoxicity in water. Mutation, $343(2-3): 121-35$. https://doi.org/10.1016/0165-1218(95)90078-0.

Altinok, I., Capkin, E., \& Boran, H. (2012). Mutagenic, genotoxic and enzyme inhibitory effects of carbosulfan in rainbow trout
Oncorhynchus mykiss. Pesticide biochemistry and physiology, 102(1), 61-67.

https://doi.org/10.1016/j.pestbp.2011.10.011.

Anbumani, S., \& Mohankumar, M. N. (2019). The Piscine Erythrocyte Micronucleus Cytome Assay. In The Micronucleus Assay in Toxicology (pp. 228-242).

Arslan, Ö. Ç., Parlak, H., Katalay, S., Boyacioglu, M., Karaaslan, M. A., \& Guner, H. (2010). Detecting micronuclei frequency in some aquatic organisms for monitoring pollution of Izmir Bay (Western Turkey). Environmental monitoring and assessment, 165(1-4), 55-66. doi: 10.1007/s10661-009-0926-5. 
Arslan, Ö. Ç., Boyacioğlu, M., Parlak, H., Katalay, S., \& Karaaslan, M. A. (2015). Assessment of micronuclei induction in peripheral blood and gill cells of some fish species from Aliağa Bay Turkey. Marine pollution bulletin, 94(1-2), 4854. doi: 10.1016/j.marpolbul.2015.03.018.

Benli, A. Ç. K., Erkmen, B., \& Erkoç, F. (2016). Genotoxicity of sub-lethal di-n-butyl phthalate (DBP) in Nile tilapia (Oreochromis niloticus)/Genotoksičnost subletalne koncentracije di-n-butil ftalata (DBP-a) u nilskoj tilapiji (Oreochromis niloticus). Archives of Industrial Hygiene and Toxicology, 67(1), 25-30. doi: 10.1515/aiht-2016-67-2723.

Cavas, T., Garanko, N. N., \& Arkhipchuk, V. V. (2005). Induction of micronuclei and binuclei in blood, gill and liver cells of fishes subchronically exposed to cadmium chloride and copper sulphate. Food and Chemical Toxicology, 43(4), 569-574. doi: 10.1016/j.fct.2004.12.014.

Çavaş, T., \& Ergene-Gözükara, S. (2003). Evaluation of the genotoxic potential of lambda-cyhalothrin using nuclear and nucleolar biomarkers on fish cells. Mutation Research/Genetic Toxicology and Environmental Mutagenesis, 534(1-2), 93-99. https://doi.org/10.1016/S1383-5718(02)00246-2.

Çavaş, T., \& Ergene-Gözükara, S. (2003b). Micronuclei, nuclear lesions and interphase silver-stained nucleolar organizer regions (AgNORs) as cyto-genotoxicity indicators in Oreochromis niloticus exposed to textile mill effluent. Mutation Research/Genetic Toxicology and Environmental Mutagenesis, 538(1-2), 8191. https://doi.org/10.1016/S13835718(03)00091-3.

Çavaş, T., \& Ergene-Gözükara, S. (2005). Induction of micronuclei and nuclear abnormalities in Oreochromis niloticus following exposure to petroleum refinery and chromium processing plant effluents. Aquatic Toxicology, 74(3), 264271. doi:10.1016/j.aquatox.2005.06.001.

Çavaş, T., \& Ergene-Gözükara, S. (2005b). Genotoxicity evaluation of metronidazole using the piscine micronucleus test by acridine orange fluorescent staining. Environmental toxicology and pharmacology, 19(1). 107-111, doi:10.1016/j.etap.2004.05.007.

Çavaş, T., \& Ergene-Gözükara, S. (2005c). Micronucleus test in fish cells: a bioassay for in situ monitoring of genotoxic pollution in the marine environment. Environmental and molecular mutagenesis, 46(1). 64-70, doi:10.1002/em.20130.

Çavaş, T., \& Könen, S. (2007). Detection of cytogenetic and DNA damage in peripheral erythrocytes of goldfish (Carassius auratus) exposed to a glyphosate formulation using the micronucleus test and the comet assay. Mutagenesis, 22(4), 263-268. doi:10.1093/mutage/gem012.

Çavaş, T., \& Könen, S. (2008). In vivo genotoxicity testing of the amnesic shellfish poison (domoic acid) in piscine erythrocytes using the micronucleus test and the comet assay. Aquatic Toxicology, 90(2), 154-159. https://doi.org/10.1016/j.aquatox.2008.08.011.

Çavaş, T. (2008). In vivo genotoxicity of mercury chloride and lead acetate: Micronucleus test on acridine orange stained fish cells. Food and Chemical Toxicology, 46(1), 352-358. doi:10.1016/j.fct.2007.08.015.

Cavas, T. (2011). In vivo genotoxicity evaluation of atrazine and atrazine-based herbicide on fish Carassius auratus using the micronucleus test and the comet assay. Food and Chemical Toxicology, 49(6), 1431-1435. doi: 10.1016/j.fct.2011.03.038.

Çok, İ., Ulutas, O. K., Okusluk, Ö., Durmaz, E., \& Demir, N. (2011). Evaluation of DNA damage in common carp (Cyprinus carpio L.) by comet assay for determination of possible pollution in Lake Mogan (Ankara). The Scientific World Journal, 11, 1455-1461. doi: 10.1100/tsw.2011.140.

Demir, E., Turna, F., Aksakal, S., Emre, Y., Emre, N., Yağc1, A., \& Kaya, B. (2015). The comet assay using rainbow trout (Oncorhynchus mykiss) for the detection of nutrient pollution generated from overfed fish farms in the esen stream. Fresenius Environmental Bulletin, 24(11), 3665-3671.

Doğan, D., Can, C., Kocyigit, A., Dikilitas, M., Taskin, A., \& Bilinc, H. (2011). Dimethoateinduced oxidative stress and DNA damage in Oncorhynchus mykiss. Chemosphere, 84(1), 3946. doi: 10.1016/j.chemosphere.2011.02.087.

Ergene, S., Çavaş, T., Çelik, A., Köleli, N., Kaya, F., \& Karahan, A. (2007). Monitoring of nuclear abnormalities in peripheral erythrocytes of three fish species from the Goksu Delta (Turkey): genotoxic damage in relation to water pollution. Ecotoxicology, 16(4), 385-391. doi:10.1007/s10646-007-0142-4.

Ergene, S., Çavaş, T., Çelik, A., Köleli, N., \& Aymak, C. (2007b). Evaluation of river water genotoxicity using the piscine micronucleus test. Environmental and Molecular Mutagenesis, 48(6), 421-429. doi:10.1002/em.20291.

Gobas, F. A. (2018). Modeling the accumulation and toxicity of organic chemicals in aquatic food chains. In Chemical Dynamics in Freshwater Ecosystems (pp. 129-152). CRC Press. 
Gurcu, B., Yildiz, S., Koca, Y. B. G., \& Koca, S. (2010). Investigation of histopathological and cytogenetic effects of heavy metals pollution on Cyprinus carpio (Linneaus, 1758) in the Gölmarmara Lake, Turkey. Journal of Animal and Veterinary Advances, 9(4), 798-808. doi: 10.3923/javaa.2010.798.808.

Gül, S., Özkan, O., Nur, G., \& Aksu, P. (2008). Genotoxic Effects and LC 50 Value of $\mathrm{NaOCl}$ on Orthrias angorae (Steindachner 1897). Bulletin of environmental contamination and toxicology, 80(6), 544-548. doi: 10.1007/s00128008-9404-y.

Gül, A., Benli, A. Ç. K., Ayhan, A., Memmi, B. K., Selvi, M., Sepici-Dinçel, A., ... \& Erkoç, F. (2012). Sublethal propoxur toxicity to juvenile common carp (Cyprinus carpio L., 1758): biochemical, hematological, histopathological, and genotoxicity effects. Environmental toxicology and chemistry, 31(9), 2085-2092. doi: 10.1002/etc. 1924.

Hussain, B., Sultana, T., Sultana, S., Masoud, M. S., Ahmed, Z., \& Mahboob, S. (2018). Fish ecogenotoxicology: Comet and micronucleus assay in fish erythrocytes as in situ biomarker of freshwater pollution. Saudi journal of biological sciences, 25(2), 393-398.

Jha, A. N. (2008). Ecotoxicological applications and significance of the comet assay. Mutagenesis, 23(3), 207-221. doi: 10.1093/mutage/gen014.

Kan, Y., Cengiz, E. I., Ugurlu, P., \& Yanar, M. (2012). The protective role of vitamin $\mathrm{E}$ on gill and liver tissue histopathology and micronucleus frequencies in peripheral erythrocytes of Oreochromis niloticus exposed to deltamethrin. Environmental toxicology and pharmacology, 34(2), 170-179. doi: 10.1016/j.etap.2012.03.009.

Kaur, R., Shah, T. K., Kaur, S., \& Rani, S. (2018). A review on genotoxicity in aquatic organisms and environment. The Pharma Innovation Journal, 2018; 7(1): 353-359.

Klobučar, G. I., Štambuk, A., Pavlica, M., \& Erben, R. (2006). Genotoxicity monitoring of freshwater environment: comet and micronucleus assays. In Symposium Pollutant responses in marine organisms, 62: 306-316. doi: 10.1007/s10646009-0390-6.

Koca S, Koca YB, Yildiz Ş, Gürcü B. (2008). Genotoxic and histopathological effects of water pollution on two fish species, Barbus capito pectoralis and Chondrostoma nasus in the Büyük Menderes River, Turkey. Biological Trace Element Research, 122:276-91. doi: 10.1007/s12011-007-8078-3.
Koca, Y. B., Koca, S., Yıldız, Ş., Gürcü, B., Osanç, E., Tunçbaş, O., \& Aksoy, G. (2005). Investigation of histopathological and cytogenetic effects on Lepomis gibbosus (Pisces: Perciformes) in the Çine stream (Aydın/Turkey) with determination of water pollution. Environmental Toxicology: An International Journal, 20(6), 560571. doi:10.1002/tox.20145.

Könen, S., \& Çavaş, T. (2008). Genotoxicity testing of the herbicide trifluralin and its commercial formulation Treflan using the piscine micronucleus test. Environmental and molecular mutagenesis, 49(6), 434-438. doi: 10.1002/em.20401.

Kumar, M. P., D'costa, A., \& Shyama, S. K. (2017). Genotoxic Biomarkers as Indicators of Marine Pollution. In Marine Pollution and Microbial Remediation (pp. 263-270). Springer, Singapore.

Kutluyer, F., Öğretmen, F., \& Inanan, B. E. (2016). Cryopreservation of Goldfish (Carassius auratus) Spermatozoa: Effects of Extender Supplemented with Taurine on Sperm Motility and DNA Damage. CryoLetters, 37(1), 41-46.

Mert, R., Karasu Benli, A. Ç., \& Arslan, G. (2015). Determination of histological and genotoxic effects of formalin on Nile tilapia ( $O$ reochromis niloticus L.). Aquaculture research, 46(11), 27982807.

Mustafa, S. A., Al-Subiai, S. N., Davies, S. J., \& Jha, A. N. (2011). Hypoxia-induced oxidative DNA damage links with higher level biological effects including specific growth rate in common carp, Cyprinus carpio L. Ecotoxicology, 20(6), 14551466. doi:10.1007/s10646-011-0702-5.

Obiakor, M., Okonkwo, J., Nnabude, P., \& Ezeonyejiaku, C. (2012). Eco-genotoxicology: micronucleus assay in fish erythrocytes as in situ aquatic pollution. Journal of Animal Science Advances, 2, 123-33.

Özkan, F., Gündüz, S. G., Berköz, M., \& Hunt, A. Ö. (2011). Induction of micronuclei and other nuclear abnormalities in peripheral erythrocytes of Nile tilapia, Oreochromis niloticus, following exposure to sublethal cadmium doses. Turkish Journal of Zoology,35(4), 585-592. doi: 10.3906/zoo-0907-77.

Raisuddin, S., \& Jha, A. N. (2004). Relative sensitivity of fish and mammalian cells to sodium arsenate and arsenite as determined by alkaline single-cell gel electrophoresis and cytokinesisblock micronucleus assay. Environmental and molecular mutagenesis, 44(1), 83-89. doi: 10.1002/em.20027.

Schweitzer, L., \& Noblet, J. (2018). Water contamination and pollution. In Green Chemistry (pp. 261-290). Elsevier. 
Selvi, M., Çavaş, T., Cağlan Karasu Benli, A., Koçak Memmi, B., Çinkılıç, N., Dinçel, A. S., ... \& Erkoç, F. (2013). Sublethal toxicity of esbiothrin relationship with total antioxidant status and in vivo genotoxicity assessment in fish (Cyprinus carpio L., 1758) using the micronucleus test and comet assay. Environmental toxicology, 28(11), 644-651. doi:10.1002/tox.20760.

Summak, S., Aydemir, N. C., Vatan, O., Yılmaz, D., Zorlu, T., \& Bilaloğlu, R. (2010). Evaluation of genotoxicity from Nilufer Stream (Bursa/Turkey) water using piscine micronucleus test. Food and Chemical Toxicology, 48(8-9), 2443-2447. https://doi.org/10.1016/j.fct.2010.06.007.

Şişman, T. (2009). Early life stage and genetic toxicity of stannous chloride on zebrafish embryos and adults: toxic effects of tin on zebrafish. Environmental toxicology, 26: 240249. doi 10.1002/tox.20550.

Ulupınar, M. \& Okumuş, İ. (2001). Detection of mutagenic-carcinogenic pollutants in aquatic systems using cytogenetic methods in fish. Turkish Journal of Zoology, 26:141-8.

Villela, I. V., de Oliveira, I. M., da Silva, J., \& Henriques, J. A. P. (2006). DNA damage and repair in haemolymph cells of golden mussel (Limnoperna fortunei) exposed to environmental contaminants. Mutation Research/Genetic Toxicology and Environmental Mutagenesis, 605(1-2), 78-86. doi:10.1016/j.mrgentox.2006.02.006.

Wells, P. G. (1999). Biomonitoring the health of coastal marine ecosystems-the roles and challenges of microscale toxicity tests. Marine Pollution Bulletin, 39(1-12), 39-47. https://doi.org/10.1016/S0025-326X(99)00120-4.

Yazıc1, Z., Şişman, T. (2014). Genotoxic effects of water pollution on two fish species living in Karasu River, Erzurum, Turkey. Environmental monitoring and assessment, 186(11), 8007-8016. doi:10.1007/s10661-014-3983-3.

Yildiz, S., Gurcu, B., Koca, Y. B., \& Koca, S. (2010). Histopathological and genotoxic effects of pollution on Anguilla anguilla in the Gediz River (Turkey). Journal of Animal and Veterinary Advances, 9(23), 2890-2899. doi: 10.3923/javaa.2010.2890.2899.

Žegura, B., \& Filipič, M. (2019). The application of the Comet assay in fish cell lines. Mutation Research/Genetic Toxicology and Environmental Mutagenesis, 842, 72-84. https://doi.org/10.1016/j.mrgentox.2019.01.011. 